\title{
Fetal conotruncal heart anomalies: is four-chamber view sufficient in the prenatal screening?
}

\author{
Başak Kaya' (D), Deniz Kanber Açar ${ }^{2}$ (D) , Ahmet Tayyar ${ }^{1}$ (D), Helen Bornaun ${ }^{3}$ (D), \\ Pelin Ayyıldız ${ }^{4}$, İbrahim Polat ${ }^{5}$ \\ ${ }^{1}$ Perinatology Unit, Department of Obstetrics and Gynecology, İstanbul Medipol University, Istanbul, Turkey \\ ${ }^{2}$ Perinatology Clinic, Dr. Sadi Konuk Training and Research Hospital, University of Health Sciences, Istanbul, Turkey \\ ${ }^{3}$ Pediatric Cardiology Clinic, Kanuni Sultan Sïleyman Training and Research Hospital, University of Health Sciences, Istanbul, Turkey \\ ${ }^{4}$ Pediatric Cardiology Clinic, Mehmet Akif Ersoy Thoracic and Cardiovascular Surgery Training and Research Hospital, University of Health Sciences, İstanbul, Turkey \\ ${ }^{5}$ Perinatology Unit, Gynecology and Obstetrics Clinic, Kanuni Sultan Siileyman Training and Research Hospital, Health Sciences University, İstanbul, Turkey
}

\begin{abstract}
Objective: In this study, we aimed to assess the factors leading to the diagnosis of conotruncal heart anomaly in the prenatal period by reviewing the records of the cases which were diagnosed with the conotruncal heart anomaly in our perinatology unit, and to raise the awareness of the diagnosis of prenatal conotruncal heart anomaly.

Methods: The referral reasons, the presence of concomitant non-cardiac anomaly and chromosomal anomaly, perinatal outcomes of the cases and the confirmation success of the diagnosis at postnatal period of the cases which were diagnosed with the conotruncal hearth anomaly at the Perinatology Unit of Kanuni Sultan Süleyman Training and Research Hospital between January 2015 and December 2016 were evaluated.

Results: Among all congenital cardiac anomalies, the incidence of conotruncal heart anomaly was $20.4 \%$. The termination of pregnancy was performed in 37 (36.6\%) of 101 cases included in the study. Intrauterine fetal death was observed in $5(5 \%)$ cases. Chromosomal anomaly and non-cardiac additional structural anomaly were found in $26.7 \%$ and $34.7 \%$ of the cases, respectively. Prenatal diagnosis was confirmed in $52(88.1 \%)$ of $59(58.4 \%)$ cases which born alive. It was found that four-chamber view was abnormal in only $27.7 \%$ of the cases. Conclusion: Three vessels (3V) and three vessels trachea (3VT) views should be displayed routinely in basic fetal cardiac screening in order to increase the prenatal diagnosis frequency of these anomalies as four-chamber view is mostly normal in conotruncal heart anomaly.
\end{abstract}

Keywords: Congenital cardiac anomalies, conotruncal heart anomalies, fetal echocardiography.
Özet: Fetal konotrunkal kalp anomalileri: Prenatal taramada dört oda görünümü yeterli mi?

Amaç: Bu çalışmada hastanemiz perinatoloji ünitesinde konotrunkal kalp anomalisi tanısı alan olguların kayıtları incelenerek prenatal dönemde konotrunkal kalp anomalisi tanısına yönlendiren faktörlerin değerlendirilmesi ve prenatal konotrunkal kalp anomalisi tanısı ile ilgili farkındalığın artırılması amaçlandı.

Yöntem: Ocak 2015 - Aralık 2016 tarihleri arasında Kanuni Sultan Süleyman Ĕ̆itim ve Araştırma Hastanesi Perinatoloji Ünitesinde konotrunkal kalp anomalisi tanısı alan olguların yönlendirilme nedenleri, eşlik eden kalp dişı anomali ve kromozom anomalisi varlı̆̆ı, olguların perinatal sonuçları ve postnatal dönemde tanının doğrulanma başarısı değerlendirildi.

Bulgular: Tüm konjenital kalp anomalilerinin içinde konotrunkal kalp anomalisi sıklığ $\% 20.4$ idi. Çalışmaya dahil edilen 101 olgunun 37'sinde (\%36.6) gebelik terminasyonu gerçekleştirildi. İntrauterin fetal ölüm 5 (\%5) olguda gözlendi. Olguların \%26.7'sinde kromozom anomalisi ve \%34.7'sinde kalp dışı ek yapısal anomali saptandı. Canlı doğan 59 (\%58.4) olgunun 52'sinde (\%88.1) prenatal tanı doğrulandı. Olguların yalnızca \%27.7'sinde dört oda görünümünün anormal olduğu saptand.

Sonuç: Dört oda görünümünün konotrunkal kalp anomalilerinde sıklıkla normal olması nedeni ile bu anomalilerin prenatal tanı sıklığının artırılabilmesi için temel fetal kardiyak tarama programlarında üç damar ve üç damar trakea kesitleri rutin olarak görüntülenmelidir.

Anahtar sözcükler: Konjenital kalp anomalileri, konotrunkal kalp anomalileri, fetal ekokardiyografi.

Correspondence: Başak Kaya, MD. Perinatology Unit, Department of Obstetrics and Gynecology, İstanbul Medipol University, İstanbul, Turkey. e-mail: kayabasak84@gmail.com / Received: September 4, 2019; Accepted: September 30, 2019

Bu yazının atıf künyesi: Kaya B, Açar DK, Tayyar A, Bornaun H, Ayyıldız P, Polat İ. Fetal conotruncal heart anomalies: is four-chamber view sufficient in the prenatal screening? Perinatal Journal 2019;27(2):113-118. doi:10.2399/prn.19.0272010 


\section{Introduction}

The migration anomaly of cardiac neural crest cells causes conotruncal heart anomalies characterized by defect in the conotruncal septum. ${ }^{[1]}$ It has been reported that $10-12 \%$ of all cardiac anomalies are conotruncal heart anomalies in the postnatal series ${ }^{[2,3]}$ and $16-30 \%$ in the prenatal series. $^{[4-8]}$

Due to the necessity of evaluation and treatment in the early postpartum period in the presence of fetal conotruncal heart anomaly, identifying these anomalies during intrauterine period is of vital importance. ${ }^{[9,10]}$ The prenatal diagnosis also enables to investigate concomitant structural and chromosomal anomalies, provide consultancy to the family through multidisciplinary approach and plan the labor in appropriate tertiary centers. However, four-chamber view being normal in the majority of conotruncal anomalies makes it difficult to establish diagnosis during prenatal period. ${ }^{[6]}$ Therefore, the rates of detecting conotruncal heart anomalies are low in the screening programs where ventricle outlets are not examined and only four-chamber view is evaluated. ${ }^{[5,11]}$

In this study, we reviewed the records of the cases which were diagnosed with the conotruncal heart anomaly in the perinatology unit of our hospital. We evaluated the reasons for referral to our hospital, the presence of concomitant non-cardiac anomaly and chromosomal anomaly, perinatal outcomes of the cases, and the confirmation success of the diagnosis at postnatal period. Our main purpose in this study is to assess the factors leading to the diagnosis of conotruncal heart anomaly in the prenatal period, and to raise the awareness of the diagnosis of prenatal conotruncal heart anomaly.

\section{Methods}

The records of 537 cases diagnosed with fetal cardiac anomaly in the Perinatology Unit of Kanuni Sultan Süleyman Training and Research Hospital between January 2015 and December 2016 were reviewed. Of 110 cases which were diagnosed with double outlet right ventricle, transposition of the great arteries (TGA), tetralogy of Fallot (TOF) and truncus arteriosus (TA), the records of 101 were reviewed after 9 cases which did not come for follow-ups and whose postnatal outcomes could not accessed were excluded from the study. The approval of ethics committee for this study was obtained from the Ethics Committee of İstanbul Medipol University with the decision no. E.45864.
All fetal ultrasonographic examinations were carried out by maternal-fetal medicine specialists via Voluson 730 and Voluson E6 (GE Medical Systems, Milwaukee, WI, USA) ultrasonography devices. Multiple planes were used in the fetal echocardiographic examinations including four-chamber view, right and left ventricle outlets, three vessels $(3 \mathrm{~V})$ and three vessels trachea $(3 \mathrm{VT})$ views, and long and short axial views (Figs. $1 \& 2$ ). The relationship and the localization of great vessels, outlet narrowness and the presence of ventricular septal defect (VSD) were reported. Detailed anatomic examination was performed in all fetuses by fetal echocardiography. After the diagnosis, the family was informed by maternal-fetal medicine specialist, pediatric cardiologist and medical genetic specialist. They were informed about the anomaly type, its potential relationship with chromosomal anomalies, potential fetal and postnatal prognosis, and the options that may be exercised in the management of pregnancy. The presence of chromosomal anomaly was evaluated by chorionic villus sampling, amniocentesis or cordocentesis in the prenatal period and by peripheral blood culture in the postnatal period in case of the clinical suspicion. The cases whose echocardiography, cardiac catheterization or surgical records could be accessed in the postnatal period were included in the study.

SPSS version 24 (Statistical Package for the Social Sciences; SPSS Inc., Chicago, IL, USA) was used for

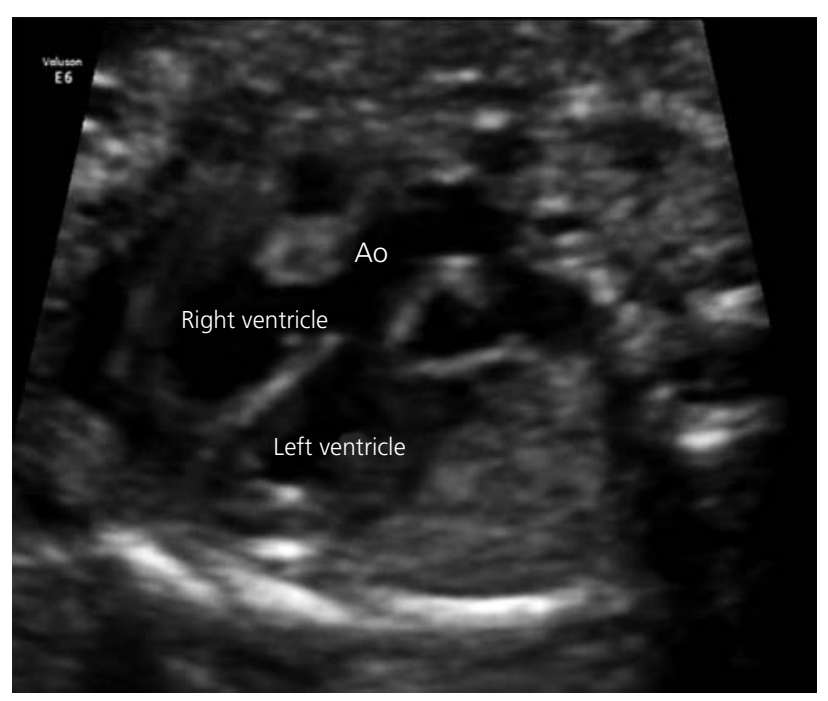

Fig. 1. The view of left ventricle outlet in the case with the tetralogy of Fallot. The distortion in the continuity between aort and ventricular septum is seen. Ao: Aort. 
the statistical analyses. The descriptive statistics were given as mean \pm standard deviation, median (minimum-maximum) and number (percentage).

\section{Results}

During 24-month study period, 110 (20.4\%) of 537 cases, which were diagnosed with congenital cardiac anomaly, had conotruncal heart anomaly. Nine cases, which did not come for follow-ups and whose postnatal outcomes could not accessed, were excluded from the study. Mean maternal age of 101 cases included in the study was 30.1 years. The weeks of gestation of the cases at the diagnosis varied between 16 and 39. The demographic characteristics of the cases are shown in the Table 1. The number of fetal echo test per case during diagnosis and follow-up varied between 1 and 4. It was found that the suspicion of fetal cardiac anomaly, the suspicion of non-cardiac structural anomaly, history of baby with congenital cardiac disease, family history and the presence of concomitant maternal disease were the major reasons for referral to our hospital.

The termination of pregnancy was performed in 37 (36.6\%) of 101 cases included in the study. Of 37 cases which were terminated, 27 (73\%) had non-cardiac additional structural anomaly and $20(54.1 \%)$ had chromosomal anomaly. Intrauterine fetal death was observed in 5 (5\%) cases. Gestational outcomes by diagnosis groups are shown in Table 2. Prenatal diagnosis was confirmed in $52(88.1 \%)$ of $59(58.4 \%)$ cases which born alive. Of the cases born alive, the mean birth was 38.1 weeks, the mean birth weight was $2943 \mathrm{~g}$, and the median values of 1-minute and 5-minute Apgar scores were 7 and 9, respectively. Eighteen (30.5\%) of 59 cases born alive died at newborn period. The survival rate after the newborn period was $40.5 \%$ in all cases. The characteristics of the cases born alive are shown in Table 3 .

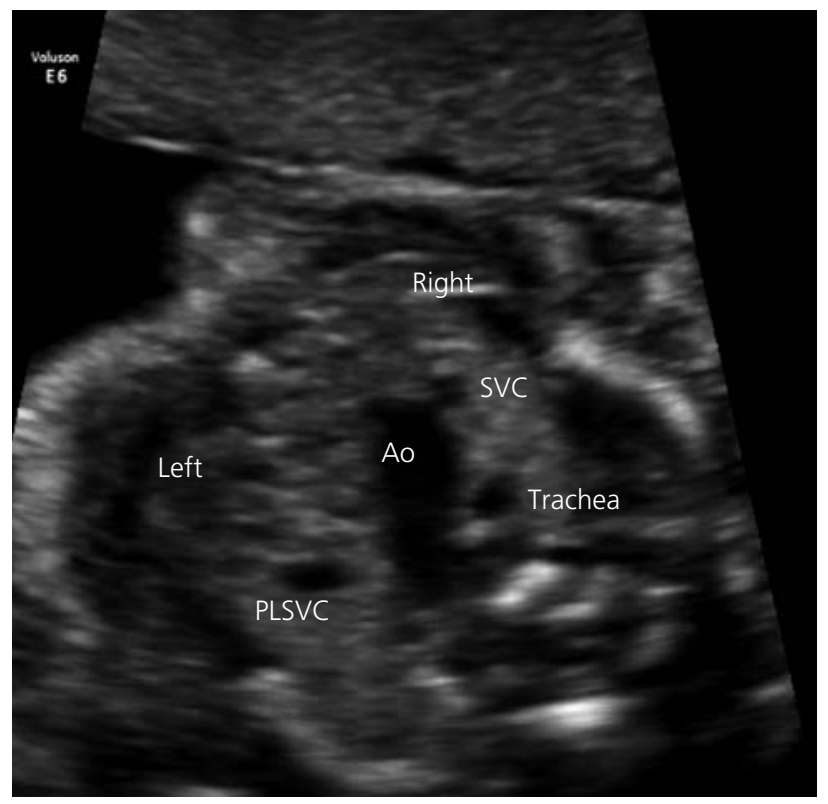

Fig. 2. Three vessels trachea view in the case with the tetralogy of Fallot. Aortic arc is seen on the left of the trachea but not the ductal arc. Ao: Aort; PLSVC: Persistent left superior vena cava; SVC: Superior vena cava.

Table 1. The demographic characteristics of the cases and their distribution by the diagnosis groups.

\begin{tabular}{lc}
\hline $\begin{array}{l}\text { The number of fetuses diagnosed with prenatal } \\
\text { conotruncal heart anomaly }\end{array}$ & 101 \\
Maternal age (year) & $30.1 \pm 6.2$ \\
Gravida & $2(1-10)$ \\
Parity & $1(0-5)$ \\
Alive & $1(0-4)$ \\
Week of gestation at diagnosis (week) & $25.4 \pm 5.8$ \\
Number of fetal echocardiography & $1(1-4)$ \\
Double outlet right ventricle & $45(44.6 \%)$ \\
Transposition of great arteries & $22(21.8 \%)$ \\
Tetralogy of Fallot & $29(28.7 \%)$ \\
Truncus arteriosus & $5(5 \%)$ \\
\hline
\end{tabular}

The data were given as mean $\pm \mathrm{SD}$, median (min-max) or number (percentage).

Table 2. Gestational outcomes by diagnosis groups.

\begin{tabular}{|c|c|c|c|c|c|}
\hline & $\begin{array}{l}\text { Double outlet right } \\
\text { ventricle }(n=45)\end{array}$ & $\begin{array}{c}\text { TGA } \\
(n=22)\end{array}$ & $\begin{array}{c}\text { TOF } \\
(n=29)\end{array}$ & $\begin{array}{c}\text { TA } \\
(n=5)\end{array}$ & $\begin{array}{l}\text { Total } \\
(n=101)\end{array}$ \\
\hline Termination of pregnancy & $18(40 \%)$ & $2(9.1 \%)$ & $16(55.2 \%)$ & $1(20 \%)$ & $37(36.6 \%)$ \\
\hline Intrauterine fetal death & $3(6.7 \%)$ & $1(4.5 \%)$ & $1(3.4 \%)$ & 0 & $5(5 \%)$ \\
\hline Live birth & $24(53.3 \%)$ & $19(86.4 \%)$ & $12(41.4 \%)$ & $4(80 \%)$ & $59(58.4 \%)$ \\
\hline Non-cardiac additional structural anomaly & $17(37.8 \%)$ & $4(18.2 \%)$ & $13(44.8 \%)$ & $1(20 \%)$ & $35(34.7 \%)$ \\
\hline Presence of chromosomal anomaly & $13(28.9 \%)$ & $1(4.5 \%)$ & $12(41.4 \%)$ & $1(20 \%)$ & $27(26.7 \%)$ \\
\hline
\end{tabular}

TA: Truncus arteriosus; TGA: Transposition of great arteries; TOF: Tetralogy of Fallot. The data were given as number (percentage). 
Table 3. The characteristics of the cases born alive.

\begin{tabular}{lc}
\hline Delivery week (weeks) & $38.1 \pm 1.91$ \\
Birth weight (g) & $2943 \pm 602$ \\
1-minute Apgar score & $7(5-9)$ \\
5-minute Apgar score & $9(7-10)$ \\
Sex (male) & $37(62.7 \%)$ \\
Death in the newborn period & $18(30.5 \%)$ \\
\hline
\end{tabular}

The data were given as mean $\pm \mathrm{SD}$, median (min-max) or number (percentage).

While 19 (70.4\%) of 27 cases, who were found to have chromosomal anomaly, had concomitant non-cardiac structural anomaly, the cardiac anomaly was in isolated form in the remaining $8(29.6 \%)$ cases. $34.7 \%$ of the cases had non-cardiac additional structural anomaly. Additional structural anomalies were found in $37.8 \%$ of the cases with double outlet right ventricle and in $44.8 \%$ of the cases with the tetralogy of Fallot. The prognoses of the cases with non-cardiac additional structural anomaly and/or chromosomal anomaly are shown in Table 4.

\section{Discussion}

Conotruncal heart anomalies comprise the majority of cyanotic congenital heart diseases observed in the first year of life. ${ }^{[12]}$ It was reported that the prenatal diagnosis of these anomalies may decrease postnatal hypoxia and perioperative mortality. ${ }^{[13,14]}$ Depending on the method used in the screening of congenital heart diseases, the prenatal diagnosis rates reported for conotruncal heart anomalies vary between $39 \%$ and $80 \% .{ }^{[5,11,13,15]}$ In this study where we evaluated the characteristics and perinatal outcomes of the cases diagnosed with conotruncal heart anomaly in the prenatal period, we found that conotruncal heart anomalies can be identified with a high accuracy in the prenatal peri-

Table 4. The prognoses of isolated and non-isolated cases.

\begin{tabular}{lcc} 
& & $\begin{array}{c}\text { Cases with additional } \\
\text { structural anomaly } \\
\text { and/or chromosomal } \\
\text { anomaly }(\mathbf{n}=\mathbf{4 3})\end{array}$ \\
\hline Termination of pregnancy & $5(8.6 \%)$ & $32(74.4 \%)$ \\
Intrauterine fetal death & $1(1.7 \%)$ & $4(9.3 \%)$ \\
Live birth & $52(89.7 \%)$ & $7(16.3 \%)$ \\
\hline
\end{tabular}

The data were given as number (percentage). od by using multiple planes in addition to the fourchamber view in fetal cardiac screening. Consistent with the up-to-date literature, we found in our study that the diagnosis of prenatal conotruncal heart anomaly indicates poor prognosis together with the presence of concomitant non-cardiac additional structural anomaly and chromosomal anomaly.

The recent studies assessing the fetuses with the diagnosis of prenatal conotruncal heart anomaly reported that conotruncal heart anomalies comprise $16-30 \%$ of all congenital cardiac anomalies. ${ }^{[4-8]}$ Consistent with the literature, the rate of conotruncal heart anomaly among congenital cardiac anomalies was $20.4 \%$ in our series.

Some studies reported that the rate of non-cardiac additional structural anomaly is $22-37 \%$ in prenatal series in the presence of conotruncal heart anomaly. ${ }^{[4,6,7]}$ Similarly, we found in our study that the $34.7 \%$ of the cases had non-cardiac additional structural anomaly, and $77.1 \%$ of the cases with additional anomaly underwent the termination of pregnancy. High rates of termination of pregnancy seen in the fetuses with additional anomaly explain the presence of low rate of additional structural anomaly observed in postnatal series. ${ }^{[16]}$ In the cases we assessed, $48.5 \%$ of the noncardiac additional structural anomalies were central nervous system anomalies. In a similar study, Paladini et al. found that $46 \%$ of the conotruncal heart anomalies accompanied by structural anomalies were central nervous system anomalies. ${ }^{[6]}$

We found that the incidence of chromosomal anomaly in our cases was $26.7 \%$ in conformance with the up-to-date literature $(17-25 \%) .^{[4,6,7]}$ When we assessed the incidence of chromosomal anomaly by the diagnosis groups in our study which is consistent with the literature, we found that the presence of concomitant chromosomal anomaly was the highest in the cases with the tetralogy of Fallot (41.4\%) and the lowest in the cases with the transposition of the great arteries (4.5\%). It should be kept in mind during prenatal consultancy that the incidence of chromosomal anomaly varies depending on the type of conotruncal anomaly. Depending on the presence of concomitant structural anomaly and chromosomal anomaly, the pregnancy was terminated in $36.6 \%$ of the cases and fetal loss was observed in $5 \%$ of the cases in the intrauterine period. When we assessed all cases, we observed that the survival rate after newborn period was $40.5 \%$. After 
excluding the terminations and intrauterine fetal losses, the survival rates reported in the literature vary between $40 \%$ and $71 \%$ for the fetuses diagnosed with conotruncal heart anomaly. ${ }^{[4,6,7,17-19]}$ It can be suggested that the incidence of concomitant structural anomaly and chromosomal anomaly and the quality of medical care in the newborn care is responsible for these differences in the survival rates. When we evaluated the prognoses of the cases according to the diagnosis groups in our study, we found that the rates of live births were lower in the cases with the double outlet right ventricle $(53.3 \%)$ and the tetralogy of Fallot (41.4\%) depending on the presence of higher rate of chromosomal anomaly and concomitant non-cardiac structural anomaly. This finding supports the correlation between the poor perinatal prognosis and the presence of concomitant structural anomaly and chromosomal anomaly.

Four-chamber view frequently being normal in conotruncal heart anomalies decreases the rates of detecting these anomalies in the basic fetal cardiac screenings. Four-chamber view is expected to be abnormal only in the cases with wide VSD or ventricular hypoplasia. ${ }^{[6]}$ In our study, the four-chamber view was abnormal only in $27.7 \%$ of the cases while three vessels and three vessels trachea views were abnormal in all cases. Adding three vessels and three vessels trachea views, which are obtained technically more easily compared to the ventricle outlet views, into basic fetal cardiac screening will contribute to the increase of diagnosis rates in the prenatal period.

Determining the localizations and relationships of great arteries properly in the prenatal diagnosis of conotruncal heart anomalies is the major challenge of the diagnosis. The greatest errors in the diagnosis particularly in the presence of double outlet right ventricle are made while determining the orientation of the great arteries. Fetal position, maternal characteristics, week of gestation and the presence of additional anomalies particularly affecting fetal thorax complicate the diagnosis. ${ }^{[1,20]}$ We found in our study that 7 cases whose prenatal diagnoses could not be confirmed were diagnosed with another conotruncal anomaly in the postnatal period. The most important reason is the failure of proper identification of the localizations of great arteries and their relationship among themselves. The relationships of great arteries with each other and ventricles are the other factors affecting the postnatal prognosis of VSD localization and outlet narrowness. ${ }^{[20]}$ Therefore, defining these parameters in detail in the presence of conotruncal heart anomaly diagnosis is very important for the prenatal consultancy given to the family.

The retrospective design of the study, the presence of the cases excluded from the study, failure of confirming the diagnosis by autopsy in the cases which were terminated and lost in the intrauterine period are the major limitations of our study.

\section{Conclusion}

In consideration of the results of our study and reported in the literature, it is understood that the fetal echocardiography conducted by using multiple planes in the referral centers is successful in the prenatal diagnosis of conotruncal heart anomalies. The prenatal diagnosis of fetal cardiac anomalies will help the identification of chromosomal anomalies and additional structural anomalies which may be associated as well as to provide proper consultancy to the family, plan the labor under appropriate conditions, take precautions for the cardiorespiratory problems that may be faced when switching from fetal life to postnatal life, and therefore to decrease social and legal problems that may arise.

The development of sonography technology, raising the awareness of the significance of prenatal diagnosis of cardiac anomalies, referring risk groups to targeted fetal echocardiography, and particularly adding three vessels and three vessels trachea views into the basic fetal cardiac screening will contribute to increase the frequency of prenatal diagnosis of these cases.

Conflicts of Interest: No conflicts declared.

\section{References}

1. Hutson MR, Kirby ML. Neural crest and cardiovascular development: a 20-year perspective. Birth Defects Res C Embryo Today 2003;69:2-13.

2. Hoffman JI, Kaplan S. The incidence of congenital heart disease. J Am Coll Cardiol 2002;39:1890-900.

3. Samanek M, Voriskova M. Congenital heart disease among 815,569 children born between 1980 and 1990 and their 15year survival: a prospective Bohemia survival study. Pediatr Cardiol 1999;20:411-7.

4. Galindo A, Mendoza A, Arbues J, Graneras A, Escribano D, Nieto O. Conotruncal anomalies in fetal life: accuracy of diag- 
nosis, associated defects and outcome. Eur J Obstet Gynecol Reprod Biol 2009;146:55-60.

5. Rustico MA, Benettoni A, D'Ottavio G, Maieron A, FischerTamaro I, Conoscenti G, et al. Fetal heart screening in lowrisk pregnancies. Ultrasound Obstet Gynecol 1995;6:313-9.

6. Paladini D, Rustico M, Todros T, Palmieri S, Gaglioti P, Benettoni A, et al. Conotruncal anomalies in prenatal life. Ultrasound Obstet Gynecol 1996;8:241-6.

7. Sivanandam S, Glickstein JS, Printz BF, Allan LD, Altmann $\mathrm{K}$, Solowiejczyk DE, et al. Prenatal diagnosis of conotruncal malformations: diagnostic accuracy, outcome, chromosomal abnormalities, and extracardiac anomalies. Am J Perinatol 2006;23:241-5.

8. Boudjemline Y, Fermont L, Le Bidois J, Fraisse A, Kachaner J, Villain E, et al. Prenatal diagnosis of conotruncal heart diseases. Results in 337 cases. [Article in French] Arch Mal Coeur Vaiss 2000;93:583-6.

9. Yoo SJ, Golding F, Jaeggi E. Ventricular outflow tract anomalies: so-called conotruncal anomalies. In: Yagel S, Silverman NH, Gembruch U, editors. Fetal cardiology. 2nd ed. New York, NY: Informa Healthcare; 2009. p. 305-27.

10. Aydemir NA, Güven MA, Bakır İ, Enç Y, Bilal MS. Importance of prenatal diagnosis in transposition of the great arteries: case report. Perinatal Journal 2007;15:68-72.

11. Vergani P, Mariani S, Ghidini A, Schiavina R, Cavallone M, Locatelli A, et al. Screening for congenital heart disease with the four-chamber view of the fetal heart. Am J Obstet Gynecol 1992;167:1000-3.

12. Gedikbasi A, Oztarhan K, Gul A, Sargin A, Ceylan Y. Diagnosis and prognosis in double-outlet right ventricle. Am J Perinatol 2008;25:427-34.
13. Bonnet D, Coltri A, Butera G, Fermont L, Le Bidois J, Kachaner J, et al. Detection of transposition of the great arteries in fetuses reduces neonatal morbidity and mortality. Circulation 1999;99:916-8.

14. Tzifa A, Barker C, Tibby SM, Simpson JM. Prenatal diagnosis of pulmonary atresia: impact on clinical presentation and early outcome. Arch Dis Child Fetal Neonatal Ed 2007;92:F199-203.

15. Wyllie J, Wren C, Hunter S. Screening for fetal cardiac malformations. Br Heart J 1994;71(4 Suppl):20-7.

16. Lurie IW, Kappetein AP, Loffredo CA, Ferencz C. Non-cardiac malformations in individuals with outflow tract defects of the heart: the Baltimore-Washington Infant Study (1981-1989). Am J Med Genet 1995;59:76-84.

17. Allan LD, Sharland GK, Milburn A, Lockhart SM, Groves AM, Anderson RH, et al. Prospective diagnosis of 1006 consecutive cases of congenital heart disease in the fetus. J Am Coll Cardiol 1994;23:1452-8.

18. Tometzki AJ, Suda K, Kohl T, Kovalchin JP, Silverman NH. Accuracy of prenatal echocardiographic diagnosis and prognosis of fetuses with conotruncal anomalies. J Am Coll Cardiol 1999;33:1696-701.

19. Kaguelidou F, Fermont L, Boudjemline Y, Le Bidois J, Batisse A, Bonnet D. Foetal echocardiographic assessment of tetralogy of Fallot and postnatal outcome. Eur Heart J 2008;29: 1432-8.

20. Gelehrter S, Owens ST, Russell MW, van der Velde ME, Gomez-Fifer C. Accuracy of the fetal echocardiogram in double-outlet right ventricle. Congenit Heart Dis 2007;2: $32-7$. 